Article

\title{
Assessing Ecosystem Services of Atmospheric Calcium and Magnesium Deposition for Potential Soil Inorganic Carbon Sequestration
}

\author{
Elena A. Mikhailova ${ }^{1, *}$, Hamdi A. Zurqani ${ }^{1,2}$, Christopher J. Post ${ }^{1}$ and Mark A. Schlautman ${ }^{3}$ \\ 1 Department of Forestry and Environmental Conservation, Clemson University, Clemson, SC 29634, USA; \\ h.zurqani@gmail.com (H.A.Z.); cpost@clemson.edu (C.J.P.) \\ 2 Department of Soil and Water Sciences, University of Tripoli, Tripoli 13538, Libya \\ 3 Department of Environmental Engineering and Earth Sciences, Clemson University, Anderson, SC 29625, \\ USA; mschlau@clemson.edu \\ * Correspondence: eleanam@clemson.edu; Tel.: +1-864-656-3535
}

Received: 13 March 2020; Accepted: 18 May 2020; Published: 25 May 2020

check for updates

\begin{abstract}
Many soil regulating ecosystem services (ES) are linked to Earth's atmosphere, but associated monetary values often are unknown or difficult to quantify. Atmospheric deposition of calcium $\left(\mathrm{Ca}^{2+}\right)$ and magnesium $\left(\mathrm{Mg}^{2+}\right)$ are abiotic flows (wet, dry, and total) from the atmosphere to land surfaces, which potentially can become available to sequester carbon (C) as soil inorganic carbon (SIC). However, these processes typically have not been included in economic valuations of ecosystem services. The primary objective of this study was to demonstrate an approach for valuing non-constrained potential SIC sequestration from atmospheric $\mathrm{Ca}^{2+}$ and $\mathrm{Mg}^{2+}$ deposition based on the concept of the avoided social cost of carbon dioxide emissions $\left(\mathrm{SC}-\mathrm{CO}_{2}\right)$. Maximum monetary values associated with the non-constrained potential SIC sequestration were compiled for the contiguous United States (U.S.) by soil order, land resource region (LRR), state, and region using available deposition data from the National Atmospheric Deposition Program (NRSP-3). For the entire contiguous U.S., an average annual monetary value for the non-constrained potential SIC sequestration due to atmospheric $\mathrm{Ca}^{2+}$ and $\mathrm{Mg}^{2+}$ deposition was $\$ 135 \mathrm{M}$ (i.e., $\$ 135$ million U.S. dollars, where $\mathrm{M}=$ million $=10^{6}$ ). Mollisols, Alfisols, and Entisols were soil orders with the highest average annual monetary values for non-constrained potential SIC sequestration. When normalized by land area, however, Vertisols had the highest average annual monetary values followed by Alfisols and Mollisols for non-constrained potential SIC sequestration. From a more agricultural perspective, the LRRs with the highest average annual monetary values for non-constrained potential SIC sequestration were the Western Range and Irrigated Region (D), the Central Feed Grains and Livestock Region (M), and the Central Great Plains Winter Wheat and Range Region (H). When normalized by area, the LRRs with the highest average annual monetary values were the Southwest Plateaus and Plains Range and Cotton Region (I) and the Florida Subtropical Fruit, Truck Crop and Range Region (U). Among the U.S. states, the highest average annual monetary values for non-constrained potential SIC sequestration were Texas, Kansas, and New Mexico, but when normalized by area the highest values by state were Kansas, Iowa, and Texas. Geographical regions in the contiguous U.S. with the highest average annual monetary values for non-constrained potential SIC sequestration were the South Central, Midwest, and West; when normalized by area, the highest values by region were South Central, Midwest, and Northern Plains. Constraints on maximum monetary values, based on physical, chemical, biological, economic, social, and political limitations, need to be considered and quantified to obtain more precise and accurate accounting of the ES associated with SIC sequestration due to atmospheric $\mathrm{Ca}^{2+}$ and $\mathrm{Mg}^{2+}$ deposition.
\end{abstract}


Keywords: avoided social cost; ecosystem services; flow; regulating; social cost; stock; Sustainable Development Goals (SDGs)

\section{Introduction}

Earth's atmosphere provides numerous ecosystem services (ES) which are crucial for achieving some of the United Nations (UN) 17 Sustainable Development Goals (SDGs) [1-3]. However, the value of atmospheric ES is often overlooked in ES assessments because the atmosphere is viewed as a "public good" without defined monetary value [4]. The atmosphere is a common-pool resource that plays an important role in climate regulation, which is related to SDG 13 "Climate Action" (Table 1). For example, the atmosphere provides abiotic services [5] by providing calcium $\left(\mathrm{Ca}^{2+}\right)$ and magnesium $\left(\mathrm{Mg}^{2+}\right)$ deposition flows (wet, dry, total) that can be key to soil inorganic carbon (SIC) sequestration (Figure 1) [6]. According to Thornes et al. (2010) [4], this type of ES would classify as "6. Direct use of the atmosphere for ecosystems and agriculture" with number 6 identifying rank in value compared to 12 other atmospheric services.

Table 1. Connections between regulating ecosystem services and selected Sustainable Development Goals (SDGs) in relation to atmospheric calcium and magnesium deposition for potential soil inorganic carbon (SIC) sequestration (adapted from Wood et al., 2017 [3]).

\begin{tabular}{ccc}
\hline TEEB Ecosystem Service Categories & TEEB Typology & Sustainable Development Goals (SDGs) \\
\hline Regulating & Climate regulation & SDG 13 \\
\hline
\end{tabular}

Note: The Economics of Ecosystems and Biodiversity (TEEB). SDG 13 "Climate Action".

The role of atmospheric ES in SIC sequestration is poorly understood, therefore making it difficult for economic valuations. Traditionally, ES assessments are focused on soil organic carbon (SOC) because of its biotic nature and presence at the Earth's surface [6]. In contrast to SOC, the functions of SIC are "hidden from view" [6] and its role in ES taken for granted. Soil inorganic carbon can be present in either "dissolved" or "solid" forms (Figure 1). Both forms of SIC can be net sequesters of carbon (C) from the atmosphere if the $\mathrm{Ca}^{2+}$ and/or $\mathrm{Mg}^{2}$ are derived from an "outside addition" (Figure 1). The quantities of SIC formed will depend on various factors (e.g., climate, topography, land use, etc.). This study considers the contribution and economic valuation of atmospheric $\mathrm{Ca}^{2+}$ and $\mathrm{Mg}^{2+}$ deposition for non-constrained potential SIC formation and sequestration of C. Non-constrained sequestration potential is defined as the maximum SIC sequestration potential from atmospheric $\mathrm{Ca}^{2+}$ and $\mathrm{Mg}^{2+}$ deposition without considering their actual fate in the soil.

\begin{tabular}{|c|c|c|c|}
\hline \multicolumn{4}{|c|}{ Soil Inorganic Carbon (SIC) } \\
\hline $\begin{array}{c}\text { Dissolved } \\
\text { (bicarbonates) }\end{array}$ & \multicolumn{3}{|c|}{$\begin{array}{c}\text { Solid } \\
\text { (carbonates) }\end{array}$} \\
\hline$\nabla$ & $\begin{array}{l}\text { Lithogenic } \\
\text { (primary) }\end{array}$ & \multicolumn{2}{|c|}{$\begin{array}{c}\text { Pedogenic } \\
\text { (secondary) }\end{array}$} \\
\hline $\begin{array}{l}\text { Leached into } \\
\text { shallow } \\
\text { groundwater }\end{array}$ & & $\begin{array}{l}\text { Calcitic: no net } \\
\text { sequestration }\end{array}$ & $\begin{array}{l}\text { Silicatic: net } \\
\text { sequestration } \\
\text { - outside } \\
\text { additions of } \\
\mathrm{Ca}^{2+} \text { and } \mathrm{Mg}^{2+}\end{array}$ \\
\hline $0.5-75 \mathrm{~kg} / \mathrm{ha}^{*}$ year & & \multicolumn{2}{|c|}{$0.1-0.4 \mathrm{Mg} \mathrm{C} / \mathrm{ha}^{*}$ year } \\
\hline
\end{tabular}

Figure 1. Types of soil inorganic (SIC) with numerical values of carbon sequestration in various soils (adapted from Lal et al. 2016 [7]).

Soil inorganic carbon sequestration relies on the natural and human-derived (e.g., agricultural, urban) stocks and flows of $\mathrm{Ca}^{2+}$ and $\mathrm{Mg}^{2+}$, which can be considered using a system-based approach 
for ES valuation (Table 2) [8,9]. In this case, the atmosphere contains various stocks of $\mathrm{Ca}^{2+}$ and $\mathrm{Mg}^{2}$, which can be deposited into the soil as "flows": wet, dry, and composite (wet + dry) $[8,9]$. Previous research by Goddard et al. $(2007,2009)$ [10,11] and Mikhailova et al. (2013) [12] examined potential contribution of wet $\mathrm{Ca}^{2+}$, wet $\mathrm{Mg}^{2}$, and composite (wet $\mathrm{Ca}^{2+}+$ wet $\mathrm{Mg}^{2}$ ) deposition to SIC sequestration in soil orders of the contiguous U.S. for the 10-year period (1994-2003). Mikhailova et al. (2013) [12] reported that the soil orders of Mollisols, Alfisols, and Entisols had the highest total average annual atmospheric wet $\mathrm{Ca}^{2+}$ and $\mathrm{Mg}^{2}$ deposition, expressed as potential SIC formation. Their analysis was limited because it was based solely on wet deposition and science-based boundaries (soil orders). Science-based boundaries have limited application in decision-making, which is often based on administrative boundaries (e.g., country, state, etc.). In addition, their analysis was based on only maximum possible sequestration values that are unlikely to be realized in full due to various constraints.

Table 2. Types of atmospheric calcium and magnesium stocks.

\begin{tabular}{|c|c|c|c|c|}
\hline \multicolumn{4}{|c|}{ Atmospheric Calcium $\left(\mathrm{Ca}^{2+}\right)$ and Magnesium $\left(\mathrm{Mg}^{2+}\right)$ Stocks } \\
\hline Separate Constituent Stocks & \multicolumn{3}{c|}{ Composite (Total) Stocks } \\
\hline $\mathrm{Ca}^{2+}$ & $\mathrm{Mg}^{2+}$ & $\mathrm{Ca}^{2+}$ & $\mathrm{Mg}^{2+}$ & $\mathrm{Ca}^{2+}+\mathrm{Mg}^{2+}$ \\
\hline
\end{tabular}

The objective of this study was to assess the value of potential SIC sequestration from atmospheric $\mathrm{Ca}^{2+}$ and $\mathrm{Mg}^{2+}$ deposition during a 16-year period (2000-2015), based on the concept of the avoided social cost of carbon dioxide emissions $\left(\mathrm{SC}-\mathrm{CO}_{2}\right)$, for the contiguous United States (U.S.) by soil order, land resource region (LRR), state, and region using information from the State Soil Geographic (STATSGO) database, and the National Atmospheric Deposition Program (NRSP-3) [13].

\section{Materials and Methods}

\subsection{Annual Trends in Atmospheric Deposition of Calcium and Magnesium (2000-2015)}

Maps of annual atmospheric total (wet plus dry) deposition $\left(\mathrm{kg} \mathrm{ha}^{-1}\right)$ of calcium and magnesium for the years 2000-2015 were downloaded from the website of the National Atmospheric Deposition Program (NADP) [13]. Annual mean total atmospheric $\mathrm{Ca}^{2+}$ deposition and annual mean total $\mathrm{Mg}^{2+}$ deposition each were computed from the 16 yearly raster layers using the Cell Statistics spatial analyst tool in ArcGIS ${ }^{\circledR} 10.6$ [14]. Statistical analysis revealed an overall increase of about $1.2 \%$ per year in the total average annual deposition of $\mathrm{Ca}^{2+}$ over this time period, whereas for $\mathrm{Mg}^{2+}$ there was no statistically significant increase or decrease in its total average annual deposition (Figure 2).

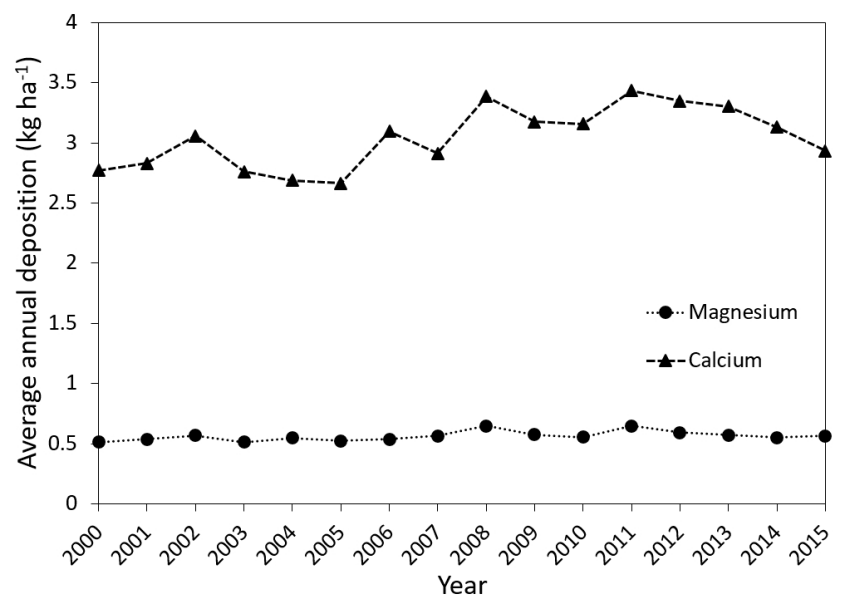

Figure 2. Temporal trends in average annual $\mathrm{Mg}^{2}$ and $\mathrm{Ca}^{2+}$ deposition values for the years 2000-2015 (National Atmospheric Deposition Program, 2019) [13]. 


\subsection{The Accounting Framework}

Total atmospheric calcium deposition and magnesium deposition (flows) from atmospheric capital to soil capital represent the amount of calcium and magnesium defined in a spatial and temporal context, which is the mass $(\mathrm{kg})$ of calcium or magnesium deposited per area (ha) to the land surface per unit time (year), which can also be defined as a mass flux or mass loading rate from the atmosphere to the land surface. In addition, these element fluxes/loading rates provide an upper limit for the maximum potential to sequester atmospheric $\mathrm{C}$ (Table 2). Table 3 provides a conceptual overview of the accounting framework for valuation of various atmospheric calcium and magnesium deposition flows: wet, dry, and total.

Table 3. Conceptual overview of the accounting framework for a systems-based approach in the ecosystem services valuation of various atmospheric magnesium deposition flows used in this study (adapted from Groshans et al., 2018 [15]).

\begin{tabular}{|c|c|c|c|c|}
\hline $\begin{array}{l}\text { Biophysical Accounts } \\
\text { (Science-Based) }\end{array}$ & $\begin{array}{l}\text { Administrative Accounts } \\
\text { (Boundary-Based) }\end{array}$ & Monetary Accounts & Benefit & Total Value \\
\hline Soil extent & Administrative extent & Ecosystem good(s) and service(s) & Sector & Types of value \\
\hline \multicolumn{5}{|c|}{ Composite (total) flows (sum of constituent flows: wet + dry): Annual mean atmospheric total $\mathrm{Ca}^{2+}$ and $\mathrm{Mg}^{2+}$ deposition } \\
\hline Soil order & $\begin{array}{l}\text { Country } \\
\text { State } \\
\text { Land Resource Region (LRR) }\end{array}$ & Regulating & $\begin{array}{l}\text { Environment: Carbon } \\
\text { sequestration (soil } \\
\text { inorganic carbon, SIC) }\end{array}$ & $\begin{array}{l}\text { Social cost of carbon }\left(\mathrm{SC}-\mathrm{CO}_{2}\right) \\
\text { and avoided emissions: } \$ 42 \text { per } \\
\text { metric ton of } \mathrm{CO}_{2}(2007 \mathrm{U} . \mathrm{S} \text {. } \\
\text { dollars with an average discount } \\
\text { rate of } 3 \%[16])\end{array}$ \\
\hline
\end{tabular}

\subsection{The Monetary Valuation}

Maps of annual mean total atmospheric deposition of $\mathrm{Ca}^{2+}$ and $\mathrm{Mg}^{2+}\left(\mathrm{kg} \mathrm{ha}^{-1}\right)$ were computed into single raster layers for each element using the Cell Statistics spatial analyst tool in ArcGIS ${ }^{\circledR}$ 10.4 [14]. The Zonal Statistics (Tables) spatial analyst tool in ArcGIS ${ }^{\circledR} 10.4$ was then used to create various Microsoft Excel tables with the appropriate raster data for each boundary (e.g., soil orders, land resource regions, states). Microsoft Excel was used to compute the maximum, non-constrained potential sequestration of SIC from atmospheric deposition and its monetary value in U.S. dollars using the following equations, based on an avoided social cost of carbon of $\$ 42 / \mathrm{Mg} \mathrm{CO}_{2}$ (applicable for the year 2020 based on 2007 U.S. dollars and an average discount rate of 3\% [16]):

$$
\begin{gathered}
\frac{\$}{h a}=\left(\mathrm{Ca}^{2+} \text { deposition, } \frac{\mathrm{kg}}{\mathrm{ha}}\right) \times \frac{1 \mathrm{Mg}}{1000 \mathrm{~kg}} \times \frac{44.01 \mathrm{MgCO}}{40.08 \mathrm{MgCa} \mathrm{Ca}^{2+}} \times \frac{\$ 42}{\mathrm{MgCO}} \\
\frac{\$}{\mathrm{~h} a}=\left(\mathrm{Mg}^{2+} \text { deposition, } \frac{\mathrm{kg}}{\mathrm{ha}}\right) \times \frac{1 \mathrm{Mg}}{1000 \mathrm{~kg}} \times \frac{44.01 \mathrm{MgCO}_{2}}{24.305 \mathrm{Mg} \mathrm{Mg}^{2+}} \times \frac{\$ 42}{\mathrm{MgCO}} \\
\$=(\text { price per area from eqn. } 1 \text { plus eqn. } 2) \times(\text { area in ha })
\end{gathered}
$$

Note that Equations (1) and (2) list SI units of kilogram ( $\mathrm{kg}$ ) and megagram (Mg) which are equal to one thousand grams and one million grams, respectively. It also can be noted that $1 \mathrm{Mg}$ is equal to 1 metric ton. For example, for the State of Indiana, the average annual non-constrained, maximum potential sequestration of SIC from $\mathrm{Ca}^{2+}$ deposition $\left(1.36 \mathrm{~kg}^{2} \mathrm{C} \mathrm{ha}{ }^{-1}\right)$ and from $\mathrm{Mg}^{2+}$ deposition $\left(0.35 \mathrm{~kg}-\mathrm{C} \mathrm{ha}{ }^{-1}\right)$ sum to a total value of $1.71 \mathrm{~kg}-\mathrm{C} \mathrm{ha}^{-1}$. Converting the latter value from $\mathrm{kg}-\mathrm{C}$ to $\mathrm{Mg}-\mathrm{CO}_{2}$, and then multiplying by the avoided social cost of carbon ( $\$ 42$ per $\mathrm{Mg}-\mathrm{CO}_{2}$ ), yields an average annual value of $\$ 0.26 \mathrm{ha}^{-1}$. Lastly, multiplying the two area-normalized values above by the area of Indiana $\left(9.36 \times 10^{6}\right.$ ha; Guo et al., 2006 [17]) yields a statewide total average of $1.60 \times 10^{7}$ total $\mathrm{kg}$ of SIC sequestered annually or $\$ 2.47 \times 10^{6}$ of avoided annual costs. 


\section{Results}

The total average annual monetary value for the non-constrained potential SIC sequestration from all atmospheric $\mathrm{Ca}^{2+}$ and $\mathrm{Mg}^{2+}$ deposition (based on a 16-year period, 2000-2015) in the contiguous U.S. is $\$ 135 \mathrm{M}$ (i.e., $\$ 135$ million U.S. dollars, where $\mathrm{M}=$ million $=10^{6}$ ). When normalized by land area, this average annual monetary value is equivalent to $\$ 0.18 \mathrm{ha}^{-1}$.

\subsection{Value of Non-Constrained Potential SIC Sequestration from Annual Mean $\mathrm{Ca}^{2+}$ and $\mathrm{Mg}^{2+}$ Deposition by Soil Order}

Soil orders with the highest average annual monetary values for non-constrained potential SIC sequestration were: Mollisols (\$39.8M), Alfisols (26.2M), and Entisols (\$17.7M). Based on area, however, the soil orders with highest average annual values for non-constrained potential SIC sequestration were: Vertisols (\$0.35 ha $\left.{ }^{-1}\right)$, Alfisols $\left(\$ 0.21 \mathrm{ha}^{-1}\right)$, and Mollisols (\$0.20 ha ${ }^{-1}$ ) (Table 4).

Table 4. Average annual total and area-normalized non-constrained potential soil inorganic carbon (SIC) sequestration within the contiguous United States (U.S.) from combined atmospheric $\mathrm{Ca}^{2+}$ and $\mathrm{Mg}^{2+}$ deposition (2000-2015) based on an avoided SC $-\mathrm{CO}_{2}$ of $\$ 42$ per metric ton of $\mathrm{CO}_{2}$ [16].

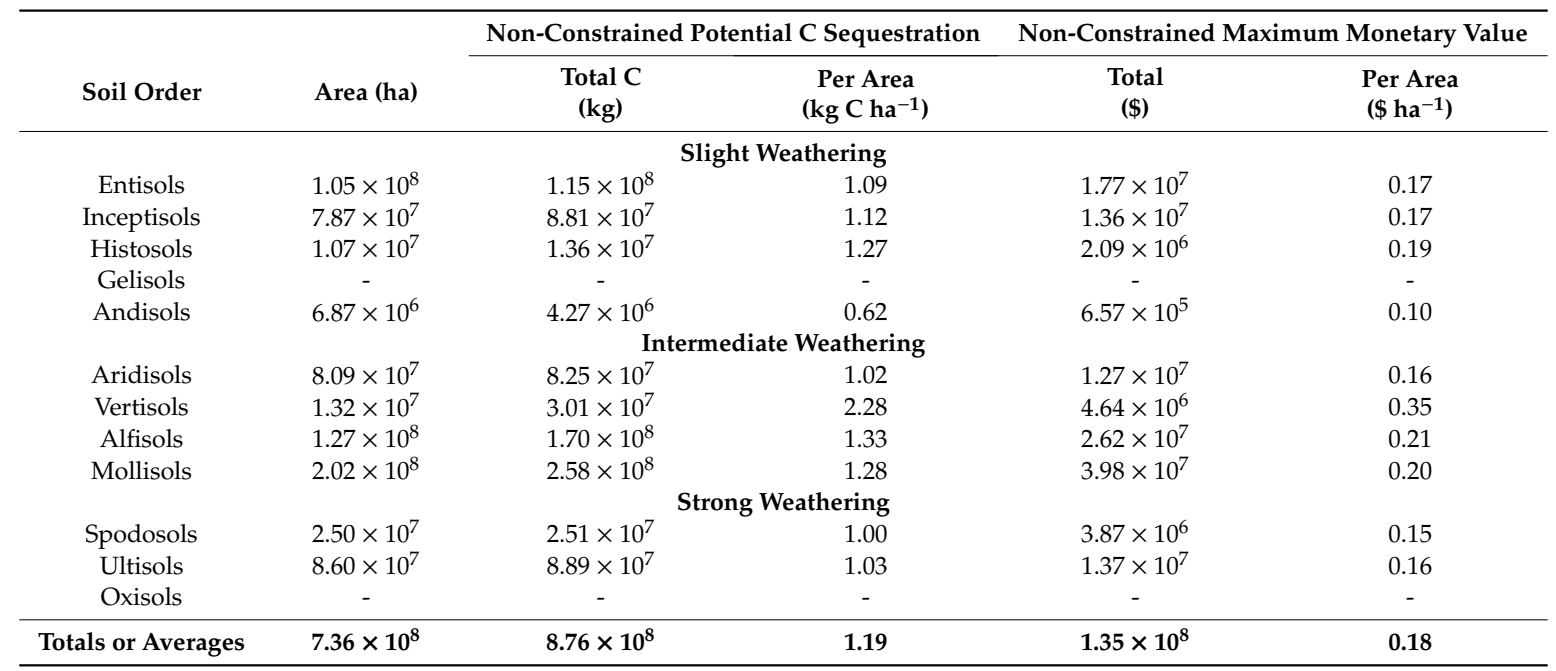

Note: Soil order areas from Guo et al. (2006) [17]. Total areas for Oxisols and Gelisols are negligible; therefore, no results are reported for these two soil orders.

3.2. Value of Non-Constrained Potential SIC Sequestration from Annual Mean $\mathrm{Ca}^{2+}$ and $\mathrm{Mg}^{2+}$ Deposition by Land Resource Regions (LRRs)

Land Resource Regions (LRRs) are defined by the U.S. Department of Agriculture (USDA) using major land resource area (MLRA) and agricultural markets, which are denoted using capital letters (e.g., A, B, C, etc.; see Table 5 notes). The contiguous U.S. (with the exception of Alaska and Hawaii) comprises 20 of the 28 LRRs (Figure 3). The LRRs with the highest average annual monetary values for non-constrained potential SIC sequestration were D (\$21.3M), M $(\$ 20.4 \mathrm{M})$, and H $(\$ 14.8 \mathrm{M})$, whereas on an area basis the LRRs with the highest average annual values were I $\left(\$ 0.35 \mathrm{ha}^{-1}\right)$ and U $\left(\$ 0.29 \mathrm{ha}^{-1}\right)$ (Table 5).

As LRRs are dominated by various soils with different inherent capacities to sequester SIC, it is important to compare area-normalized maximum values of SIC currently present in the soils with area-normalized values of SIC potential sequestration from atmospheric deposition. As a result, the following LRRs will have limited to non-existent capacities to sequester SIC from atmospheric deposition due to excessive leaching: A, N, P, R, and S. For these LRRs, soil carbon sequestration strategies may be more successful with a focus on soil organic carbon (SOC) sequestration (e.g., conservation tillage, tree planting, etc.). Some of the LRRs with arid conditions also may have limited to non-existent capacities to sequester both SOC and SIC due to lack of moisture in the soil. 
Table 5. Average annual total and area-normalized non-constrained potential soil inorganic carbon (SIC) sequestration within the contiguous United States (U.S.) from combined atmospheric $\mathrm{Ca}^{2+}$ and $\mathrm{Mg}^{2+}$ deposition (2000-2015) by Land Resource Regions (LRRs) based on an avoided SC-CO $\mathrm{C}_{2}$ of $\$ 42$ per metric ton of $\mathrm{CO}_{2}[16]$.

\begin{tabular}{|c|c|c|c|c|c|}
\hline \multirow[b]{2}{*}{ LRRs } & \multirow[b]{2}{*}{ Area (ha) } & \multicolumn{2}{|c|}{ Non-Constrained Potential C Sequestration } & \multicolumn{2}{|c|}{ Non-Constrained Maximum Monetary Value } \\
\hline & & $\begin{array}{l}\text { Total } \\
\text { (kg) }\end{array}$ & $\begin{array}{c}\text { Per Area } \\
\left(\mathrm{kg} \mathrm{C} \mathrm{ha-1)}^{-1}\right.\end{array}$ & $\begin{array}{c}\text { Total } \\
\text { (\$) }\end{array}$ & $\begin{array}{c}\text { Per Area } \\
\left(\$ \mathrm{ha}^{-1}\right)\end{array}$ \\
\hline A & $1.81 \times 10^{7}$ & $1.26 \times 10^{7}$ & 0.69 & $1.94 \times 10^{6}$ & 0.11 \\
\hline $\mathrm{B}$ & $2.59 \times 10^{7}$ & $1.06 \times 10^{7}$ & 0.41 & $1.63 \times 10^{6}$ & 0.06 \\
\hline $\mathrm{C}$ & $1.47 \times 10^{7}$ & $9.27 \times 10^{6}$ & 0.63 & $1.43 \times 10^{6}$ & 0.10 \\
\hline $\mathrm{D}$ & $1.27 \times 10^{8}$ & $1.39 \times 10^{8}$ & 1.09 & $2.13 \times 10^{7}$ & 0.17 \\
\hline $\mathrm{E}$ & $5.22 \times 10^{7}$ & $5.23 \times 10^{7}$ & 1.00 & $8.05 \times 10^{6}$ & 0.15 \\
\hline $\mathrm{F}$ & $3.52 \times 10^{7}$ & $2.97 \times 10^{7}$ & 0.84 & $4.57 \times 10^{6}$ & 0.13 \\
\hline G & $5.21 \times 10^{7}$ & $4.31 \times 10^{7}$ & 0.83 & $6.63 \times 10^{6}$ & 0.13 \\
\hline $\mathrm{H}$ & $5.84 \times 10^{7}$ & $9.64 \times 10^{7}$ & 1.65 & $1.48 \times 10^{7}$ & 0.25 \\
\hline I & $1.70 \times 10^{7}$ & $3.84 \times 10^{7}$ & 2.26 & $5.92 \times 10^{6}$ & 0.35 \\
\hline $\mathrm{J}$ & $1.40 \times 10^{7}$ & $2.55 \times 10^{7}$ & 1.83 & $3.93 \times 10^{6}$ & 0.28 \\
\hline $\mathrm{K}$ & $3.00 \times 10^{7}$ & $3.64 \times 10^{7}$ & 1.21 & $5.60 \times 10^{6}$ & 0.19 \\
\hline $\mathrm{L}$ & $1.20 \times 10^{7}$ & $1.60 \times 10^{7}$ & 1.34 & $2.47 \times 10^{6}$ & 0.21 \\
\hline M & $7.18 \times 10^{7}$ & $1.32 \times 10^{8}$ & 1.84 & $2.04 \times 10^{7}$ & 0.28 \\
\hline $\mathrm{N}$ & $6.03 \times 10^{7}$ & $7.48 \times 10^{7}$ & 1.24 & $1.15 \times 10^{7}$ & 0.19 \\
\hline $\mathrm{O}$ & $9.47 \times 10^{6}$ & $1.07 \times 10^{7}$ & 1.14 & $1.66 \times 10^{6}$ & 0.17 \\
\hline $\mathrm{P}$ & $6.77 \times 10^{7}$ & $6.39 \times 10^{7}$ & 0.94 & $9.84 \times 10^{6}$ & 0.15 \\
\hline $\mathrm{R}$ & $3.01 \times 10^{7}$ & $2.47 \times 10^{7}$ & 0.82 & $3.80 \times 10^{6}$ & 0.13 \\
\hline$S$ & $9.91 \times 10^{6}$ & $1.04 \times 10^{7}$ & 1.05 & $1.60 \times 10^{6}$ & 0.16 \\
\hline $\mathrm{T}$ & $2.31 \times 10^{7}$ & $3.57 \times 10^{7}$ & 1.54 & $5.49 \times 10^{6}$ & 0.24 \\
\hline $\mathrm{U}$ & $8.54 \times 10^{6}$ & $1.60 \times 10^{7}$ & 1.88 & $2.47 \times 10^{6}$ & 0.29 \\
\hline Totals or Averages & $7.37 \times 10^{8}$ & $8.77 \times 10^{8}$ & 1.19 & $1.35 \times 10^{8}$ & 0.18 \\
\hline
\end{tabular}

LRR abbreviations: $\mathrm{A}=$ Northwestern Forest, Forage and Specialty Crop Region; $\mathrm{B}=$ Northwestern Wheat and Range Region; $\mathrm{C}=$ California Subtropical Fruit, Truck, and Specialty Crop Region; D = Western Range and Irrigated Region; E = Rocky Mountain Range and Forest Region; F = Northern Great Plains Spring Wheat Region; $\mathrm{G}=$ Western Great Plains Range and Irrigated Region; H = Central Great Plains Winter Wheat and Range Region; I = Southwest Plateaus and Plains Range and Cotton Region; J = Southwestern Prairies Cotton and Forage Region; $\mathrm{K}=$ Northern Lake States Forest and Forage Region; L = Lake States Fruit, Truck, and Dairy Region; M = Central Feed Grains and Livestock Region; $\mathrm{N}=$ East and Central Farming and Forest Region; $\mathrm{O}=$ Mississippi Delta Cotton and Feed Grains Region; P = South Atlantic and Gulf Slope Cash Crops, Forest and Livestock Region; $\mathrm{R}=$ Northeastern Forage and Forest Region; $\mathrm{S}=$ Northern Atlantic Slope Diversified Farming Region; $\mathrm{T}=$ Atlantic and Gulf Cost Lowland Forest and Crop Region; U = Florida Subtropical Fruit, Truck, Crop, and Range Region. LRR areas from Guo et al. (2006) [17].

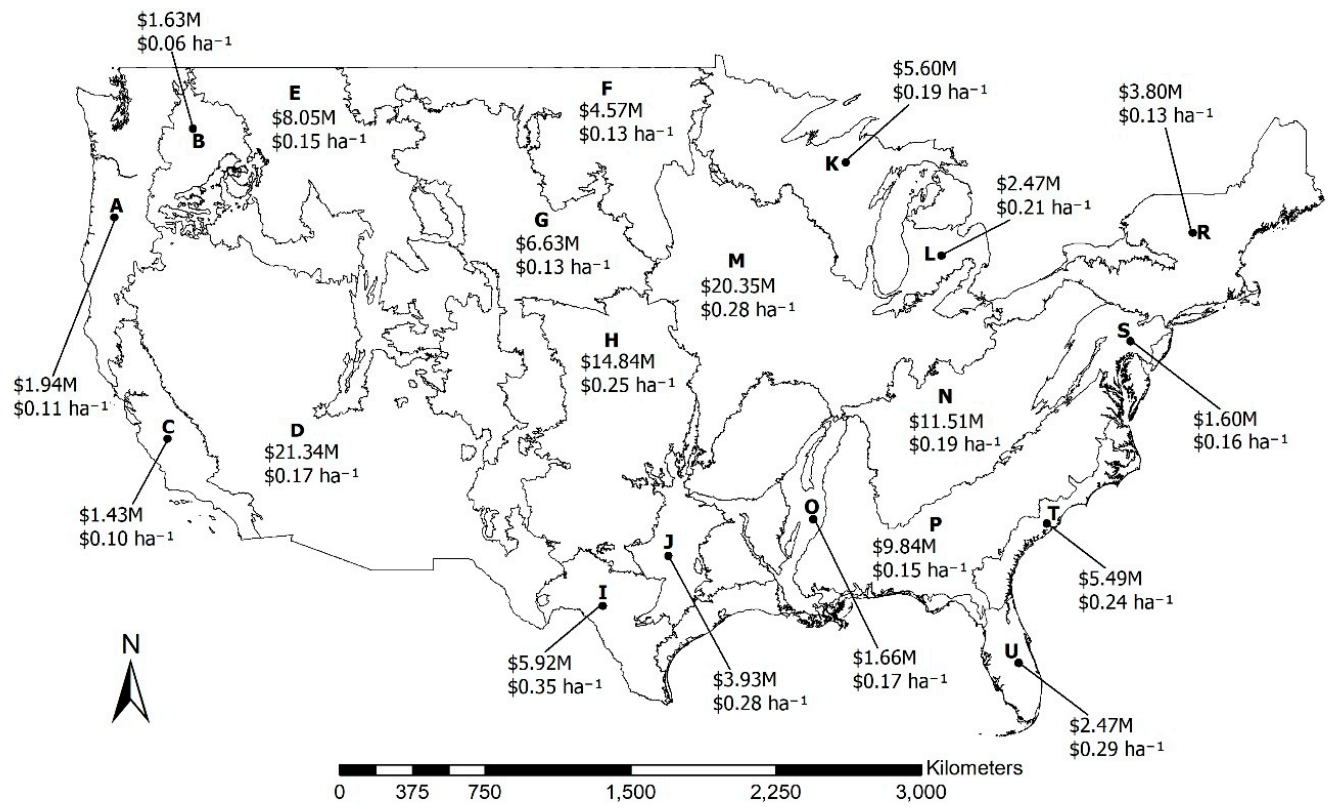

Figure 3. Average annual total (top number) and area-normalized (bottom number) monetary values of non-constrained potential soil inorganic carbon (SIC) sequestration from combined atmospheric $\mathrm{Ca}^{2+}$ and $\mathrm{Mg}^{2+}$ deposition (2000-2015) for different Land Resources Regions (LRRs) in the contiguous United States (U.S.) based on an avoided SC $-\mathrm{CO}_{2}$ of $\$ 42$ per metric ton of $\mathrm{CO}_{2}$ [16]. Note: $\mathrm{M}=$ million $=10^{6}$. 
3.3. Value of Non-Constrained Potential SIC Sequestration from Annual Mean $\mathrm{Ca}^{2+}$ and $\mathrm{Mg}^{2+}$ Deposition by States and Regions in the Contiguous U.S.

Among the U.S. states, the highest average annual monetary values for non-constrained potential SIC sequestration were Texas $(\$ 19.4 \mathrm{M})$, Kansas $(\$ 6.68 \mathrm{M})$ and New Mexico $(\$ 5.99 \mathrm{M})$, whereas based on area the order was Kansas and Iowa (both at $\$ 0.31 \mathrm{ha}^{-1}$ ) followed by Texas $\left(\$ 0.26 \mathrm{ha}^{-1}\right)($ Figure 4 , Table 6). Regions with the highest average annual monetary values for non-constrained potential SIC sequestration were (1) South Central (\$28.6M), (2) Midwest (\$27.9M), and (3) West (\$27.7M) (Figure 5, Table 6). Average annual monetary values of non-constrained potential SIC sequestration normalized by area within region boundaries were ranked: (1) South Central (\$0.26 ha $\left.{ }^{-1}\right),(2)$ Midwest $\left(\$ 0.24\right.$ ha $\left.^{-1}\right)$, and (3) Northern Plains (\$0.17 ha ${ }^{-1}$ ) (Figure 5, Table 6).

As states and regions are dominated by various soil orders with different inherent capacities to sequester SIC, it is important to compare area-normalized maximum values of SIC currently present in the soils with area-normalized values of non-constrained potential SIC sequestration from atmospheric deposition. This comparison reveals that the following states and regions will have limited to non-existent capacities to sequester SIC from atmospheric deposition: East Region (Connecticut, Delaware, Massachusetts, Maryland, Maine, New Hampshire, New Jersey, New York, Pennsylvania, Rhode Island, Vermont, and West Virginia), and Southeast Region (Alabama, Florida, Georgia, Kentucky, Mississippi, North Carolina, South Carolina, Tennessee, Virginia). Soil inorganic carbon sequestration in these states and regions can be further reduced as a result of air pollution due to burning of fossil fuels, industrial production, and urbanization. Soil carbon sequestration strategies in these states and regions may be more successful with a focus on SOC sequestration. Arid states/regions may have limited to non-existent capacities to sequester soil $\mathrm{C}$ due to inadequate soil moisture.

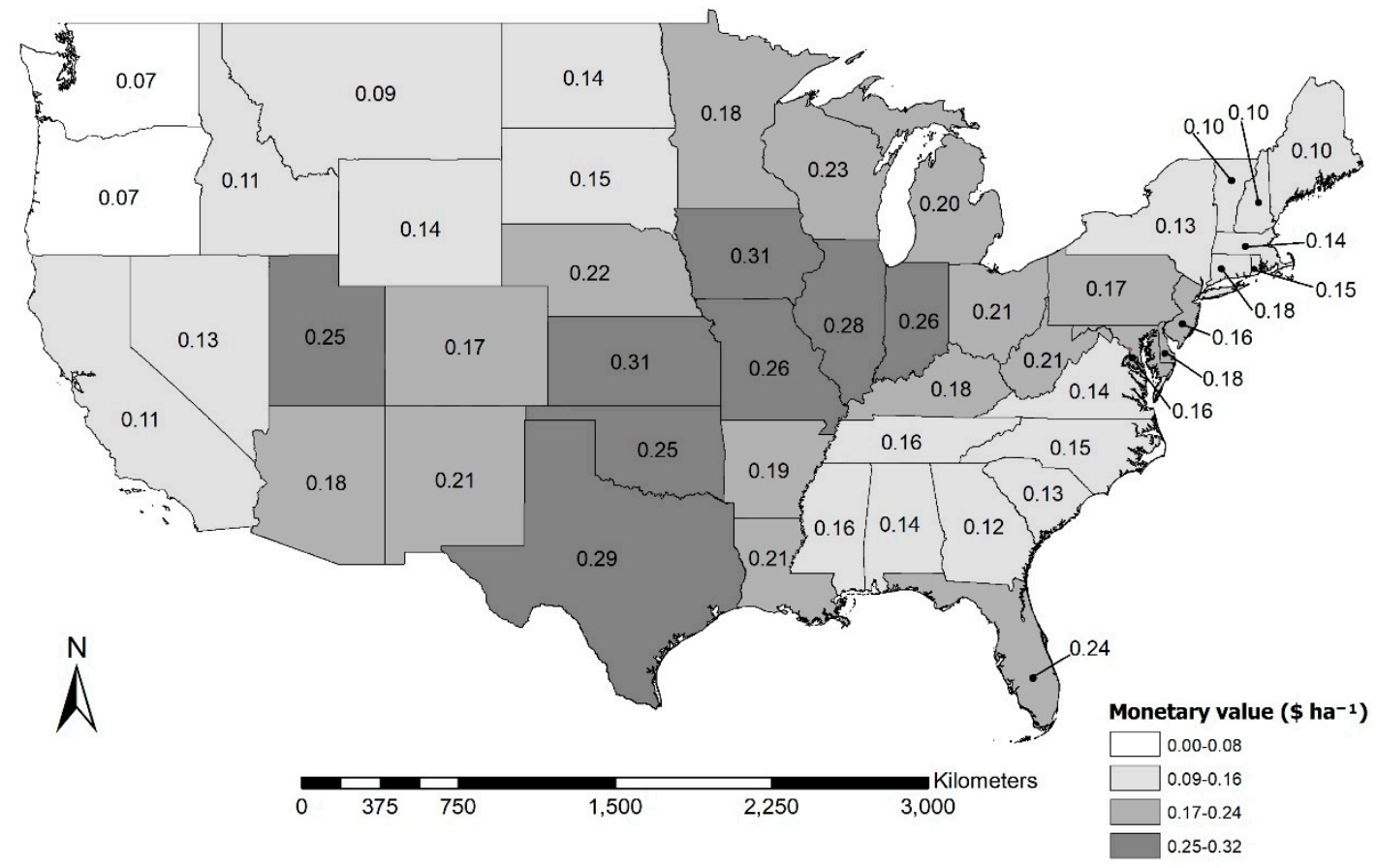

Figure 4. Average annual monetary values normalized by land area $\left(\$ \mathrm{~m}^{-2}\right)$ of non-constrained potential soil inorganic carbon (SIC) sequestration from combined atmospheric $\mathrm{Ca}^{2+}$ and $\mathrm{Mg}^{2+}$ deposition (2000-2015) for different states in the contiguous United States (U.S.) based on an avoided SC- $\mathrm{CO}_{2}$ of $\$ 42$ per metric ton of $\mathrm{CO}_{2}[16]$. 
Table 6. Average annual total and area-normalized non-constrained potential soil inorganic carbon (SIC) sequestration from combined atmospheric $\mathrm{Ca}^{2+}$ and $\mathrm{Mg}^{2+}$ deposition (2000-2015) for each state (region) within the contiguous United States (U.S.) based on an avoided SC- $\mathrm{CO}_{2}$ of $\$ 42$ per metric ton of $\mathrm{CO}_{2}$ [16].

\begin{tabular}{|c|c|c|c|c|c|}
\hline \multirow[b]{2}{*}{ State (Region) } & \multirow[b]{2}{*}{$\begin{array}{c}\text { Area (ha) } \\
{[17]}\end{array}$} & \multicolumn{2}{|c|}{ Non-Constrained Potential C Sequestration } & \multicolumn{2}{|c|}{ Non-Constrained Maximum Monetary Value } \\
\hline & & $\begin{array}{l}\text { Total } \\
\text { (kg) }\end{array}$ & $\begin{array}{c}\text { Per Area } \\
\left(\mathrm{kg} \mathrm{C} \mathrm{ha-1)}^{-1}\right)\end{array}$ & $\begin{array}{c}\text { Total } \\
\text { (\$) }\end{array}$ & $\begin{array}{c}\text { Per Area } \\
\left(\$ h^{-1}\right)\end{array}$ \\
\hline Connecticut & $1.24 \times 10^{6}$ & $1.25 \times 10^{6}$ & 1.01 & $1.93 \times 10^{5}$ & 0.16 \\
\hline Delaware & $5.04 \times 10^{5}$ & $6.01 \times 10^{5}$ & 1.19 & $9.26 \times 10^{4}$ & 0.18 \\
\hline Massachusetts & $1.89 \times 10^{6}$ & $1.73 \times 10^{6}$ & 0.92 & $2.67 \times 10^{5}$ & 0.14 \\
\hline Maryland & $2.53 \times 10^{6}$ & $2.69 \times 10^{6}$ & 1.07 & $4.15 \times 10^{5}$ & 0.16 \\
\hline Maine & $8.06 \times 10^{6}$ & $5.15 \times 10^{6}$ & 0.64 & $7.93 \times 10^{5}$ & 0.10 \\
\hline New Hampshire & $2.28 \times 10^{6}$ & $1.45 \times 10^{6}$ & 0.64 & $2.24 \times 10^{5}$ & 0.10 \\
\hline New Jersey & $1.78 \times 10^{6}$ & $2.07 \times 10^{6}$ & 1.17 & $3.19 \times 10^{5}$ & 0.18 \\
\hline New York & $1.18 \times 10^{7}$ & $1.01 \times 10^{7}$ & 0.85 & $1.55 \times 10^{6}$ & 0.13 \\
\hline Pennsylvania & $1.15 \times 10^{7}$ & $1.25 \times 10^{7}$ & 1.08 & $1.92 \times 10^{6}$ & 0.17 \\
\hline Rhode Island & $2.58 \times 10^{5}$ & $2.46 \times 10^{6}$ & 0.95 & $3.79 \times 10^{4}$ & 0.15 \\
\hline Vermont & $2.38 \times 10^{6}$ & $1.59 \times 10^{6}$ & 0.67 & $2.45 \times 10^{5}$ & 0.10 \\
\hline West Virginia & $6.14 \times 10^{6}$ & $8.20 \times 10^{6}$ & 1.33 & $1.26 \times 10^{6}$ & 0.21 \\
\hline (East) & $5.04 \times 10^{7}$ & $4.75 \times 10^{7}$ & 0.94 & $7.32 \times 10^{6}$ & 0.15 \\
\hline Iowa & $1.44 \times 10^{7}$ & $2.91 \times 10^{7}$ & 2.02 & $4.48 \times 10^{6}$ & 0.31 \\
\hline Illinois & $1.44 \times 10^{7}$ & $2.65 \times 10^{7}$ & 1.84 & $4.09 \times 10^{6}$ & 0.28 \\
\hline Indiana & $9.36 \times 10^{6}$ & $1.60 \times 10^{7}$ & 1.71 & $2.47 \times 10^{6}$ & 0.26 \\
\hline Michigan & $1.48 \times 10^{7}$ & $1.89 \times 10^{7}$ & 1.28 & $2.90 \times 10^{6}$ & 0.20 \\
\hline Minnesota & $2.09 \times 10^{7}$ & $2.49 \times 10^{7}$ & 1.19 & $3.84 \times 10^{6}$ & 0.18 \\
\hline Missouri & $1.77 \times 10^{7}$ & $3.05 \times 10^{7}$ & 1.72 & $4.69 \times 10^{6}$ & 0.26 \\
\hline Ohio & $1.05 \times 10^{7}$ & $1.46 \times 10^{7}$ & 1.38 & $2.25 \times 10^{6}$ & 0.21 \\
\hline Wisconsin & $1.41 \times 10^{7}$ & $2.08 \times 10^{7}$ & 1.48 & $3.20 \times 10^{6}$ & 0.23 \\
\hline (Midwest) & $1.16 \times 10^{8}$ & $1.81 \times 10^{8}$ & 1.56 & $2.79 \times 10^{7}$ & 0.24 \\
\hline Arkansas & $1.36 \times 10^{7}$ & $1.65 \times 10^{7}$ & 1.21 & $2.54 \times 10^{6}$ & 0.19 \\
\hline Louisiana & $1.09 \times 10^{7}$ & $1.46 \times 10^{7}$ & 1.33 & $2.24 \times 10^{6}$ & 0.21 \\
\hline Oklahoma & $1.77 \times 10^{7}$ & $2.83 \times 10^{7}$ & 1.60 & $4.35 \times 10^{6}$ & 0.25 \\
\hline Texas & $6.61 \times 10^{7}$ & $1.26 \times 10^{8}$ & 1.91 & $1.94 \times 10^{7}$ & 0.29 \\
\hline (South Central) & $1.08 \times 10^{8}$ & $1.85 \times 10^{8}$ & 1.71 & $2.86 \times 10^{7}$ & 0.26 \\
\hline Alabama & $1.31 \times 10^{7}$ & $1.19 \times 10^{7}$ & 0.91 & $1.83 \times 10^{6}$ & 0.14 \\
\hline Florida & $1.36 \times 10^{7}$ & $2.16 \times 10^{7}$ & 1.58 & $3.33 \times 10^{6}$ & 0.24 \\
\hline Georgia & $1.49 \times 10^{7}$ & $1.16 \times 10^{7}$ & 0.78 & $1.79 \times 10^{6}$ & 0.12 \\
\hline Kentucky & $1.02 \times 10^{7}$ & $1.17 \times 10^{7}$ & 1.15 & $1.80 \times 10^{6}$ & 0.18 \\
\hline Mississippi & $1.23 \times 10^{7}$ & $1.24 \times 10^{7}$ & 1.01 & $1.91 \times 10^{6}$ & 0.16 \\
\hline North Carolina & $1.26 \times 10^{7}$ & $1.20 \times 10^{7}$ & 0.96 & $1.85 \times 10^{6}$ & 0.15 \\
\hline South Carolina & $7.85 \times 10^{6}$ & $6.38 \times 10^{6}$ & 0.81 & $9.83 \times 10^{5}$ & 0.13 \\
\hline Tennessee & $1.04 \times 10^{7}$ & $1.09 \times 10^{7}$ & 1.05 & $1.68 \times 10^{6}$ & 0.16 \\
\hline Virginia & $1.03 \times 10^{7}$ & $9.12 \times 10^{6}$ & 0.89 & $1.40 \times 10^{6}$ & 0.14 \\
\hline (Southeast) & $1.05 \times 10^{8}$ & $1.08 \times 10^{8}$ & 1.02 & $1.66 \times 10^{7}$ & 0.16 \\
\hline Colorado & $2.54 \times 10^{7}$ & $2.77 \times 10^{7}$ & 1.09 & $4.26 \times 10^{6}$ & 0.17 \\
\hline Kansas & $2.12 \times 10^{7}$ & $4.34 \times 10^{7}$ & 2.04 & $6.68 \times 10^{6}$ & 0.31 \\
\hline Montana & $3.51 \times 10^{7}$ & $2.14 \times 10^{7}$ & 0.61 & $3.30 \times 10^{6}$ & 0.09 \\
\hline North Dakota & $1.79 \times 10^{7}$ & $1.59 \times 10^{7}$ & 0.89 & $2.44 \times 10^{6}$ & 0.14 \\
\hline Nebraska & $1.98 \times 10^{7}$ & $2.79 \times 10^{7}$ & 1.41 & $4.30 \times 10^{6}$ & 0.22 \\
\hline South Dakota & $1.92 \times 10^{7}$ & $1.90 \times 10^{7}$ & 0.99 & $2.92 \times 10^{6}$ & 0.15 \\
\hline Wyoming & $2.29 \times 10^{7}$ & $2.01 \times 10^{7}$ & 0.88 & $3.10 \times 10^{6}$ & 0.14 \\
\hline (Northern Plains) & $1.62 \times 10^{8}$ & $1.75 \times 10^{8}$ & 1.09 & $2.70 \times 10^{7}$ & 0.17 \\
\hline Arizona & $2.67 \times 10^{7}$ & $3.11 \times 10^{7}$ & 1.17 & $4.79 \times 10^{6}$ & 0.18 \\
\hline California & $3.54 \times 10^{7}$ & $2.51 \times 10^{7}$ & 0.71 & $3.86 \times 10^{6}$ & 0.11 \\
\hline Idaho & $1.97 \times 10^{7}$ & $1.35 \times 10^{7}$ & 0.68 & $2.07 \times 10^{6}$ & 0.11 \\
\hline New Mexico & $2.84 \times 10^{7}$ & $3.89 \times 10^{7}$ & 1.37 & $5.99 \times 10^{6}$ & 0.21 \\
\hline Nevada & $2.69 \times 10^{7}$ & $2.35 \times 10^{7}$ & 0.87 & $3.61 \times 10^{6}$ & 0.13 \\
\hline Oregon & $2.40 \times 10^{7}$ & $1.03 \times 10^{7}$ & 0.43 & $1.59 \times 10^{6}$ & 0.07 \\
\hline Utah & $1.85 \times 10^{7}$ & $3.01 \times 10^{7}$ & 1.63 & $4.64 \times 10^{6}$ & 0.25 \\
\hline Washington & $1.62 \times 10^{7}$ & $7.63 \times 10^{6}$ & 0.47 & $1.18 \times 10^{6}$ & 0.07 \\
\hline (West) & $1.96 \times 10^{8}$ & $1.80 \times 10^{8}$ & 0.92 & $2.77 \times 10^{7}$ & 0.14 \\
\hline Totals or averages & $7.37 \times 10^{8}$ & $8.77 \times 10^{8}$ & 1.19 & $1.35 \times 10^{8}$ & 0.18 \\
\hline
\end{tabular}




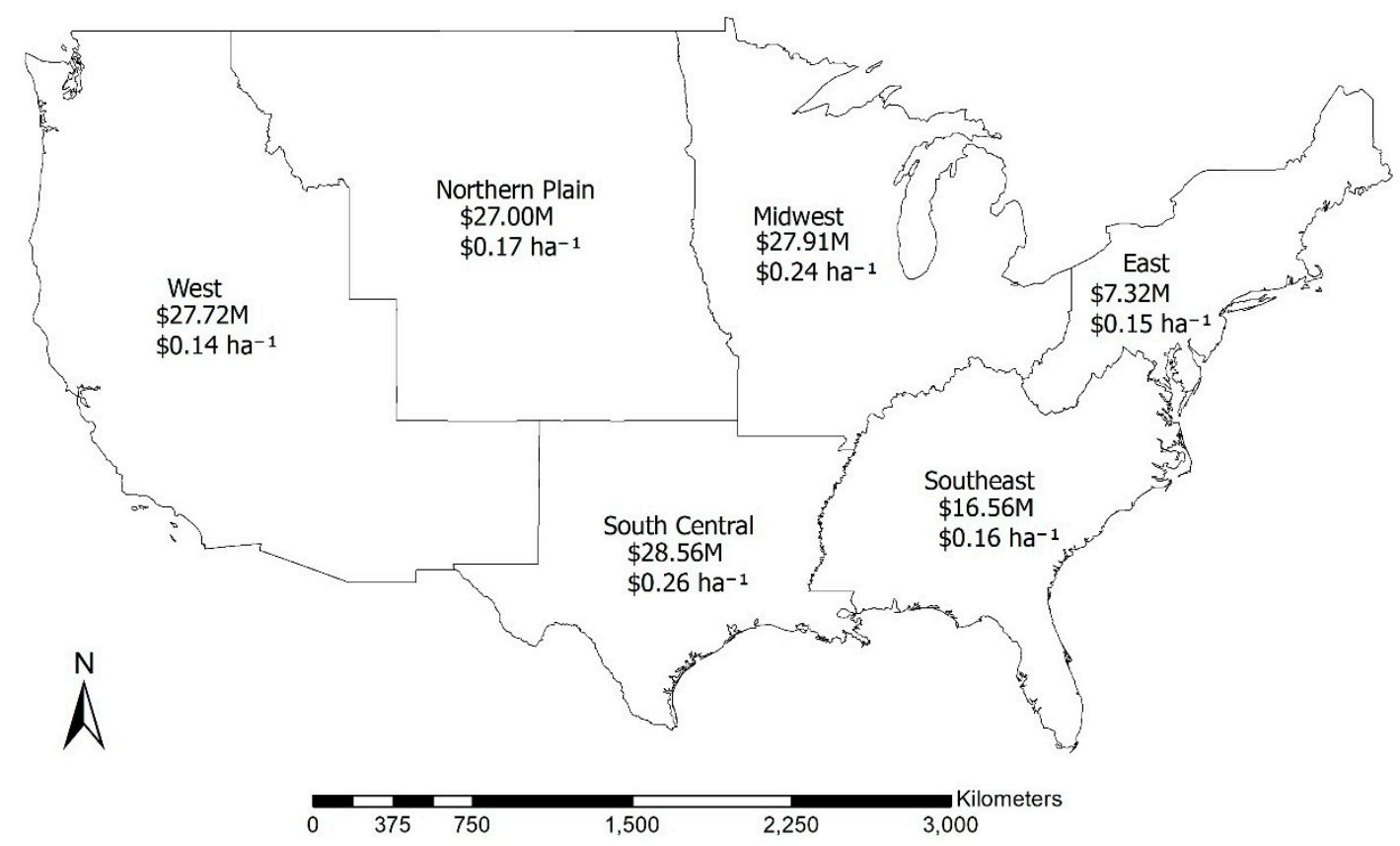

Figure 5. Average annual total (top number) and area-normalized (bottom number) monetary values of non-constrained potential soil inorganic carbon (SIC) sequestration from combined atmospheric $\mathrm{Ca}^{2+}$ and $\mathrm{Mg}^{2+}$ deposition (2000-2015) for different regions in the contiguous United States (U.S.) based on an avoided SC- $\mathrm{CO}_{2}$ of $\$ 42$ per metric ton of $\mathrm{CO}_{2}$ [16]. Note: $\mathrm{M}=$ million $=10^{6}$.

\section{Discussion}

Earth's atmosphere is an important source of ES, including abiotic ES which are commonly excluded from ES frameworks and assessments [4,6]. Contribution from atmosphere to SIC sequestration is one of the options in the "natural climate solution" (NCS) [18]. This study quantified and valued non-constrained potential SIC sequestration from atmospheric $\mathrm{Ca}^{2+}$ and $\mathrm{Mg}^{2+}$ deposition ("natural" and "human-derived") within the contiguous U.S. using science-based boundaries (soil order) and administrative boundaries (LRRs, state, and region). Non-constrained potential SIC sequestration is variable due to inherent variations in wet and dry atmospheric depositions across the contiguous U.S. From these maximum values, constraints based on physical, chemical, and/or biological limitations must be considered to obtain more precise and accurate accounting of the ES associated with SIC sequestration due to atmospheric $\mathrm{Ca}^{2+}$ and $\mathrm{Mg}^{2+}$ deposition. For example, physical properties of the rainfall (e.g., intensity, duration, frequency, interception) as well as properties of the land surface and soils themselves (e.g., land use/cover, topography, hydrologic soil group, soil texture, soil $\mathrm{pH}$, etc.) $[19,20]$ all can be expected to add limitations to the non-constrained potential and maximum values we report above. Intermediately weathered soils (with the exception of Aridisols) have a high potential to sequester SIC from atmospheric $\mathrm{Ca}^{2+}$ and $\mathrm{Mg}^{2+}$ deposition when compared with slightly weathered and highly weathered soils (Figure 6). This indicates inherent biological/physical constraints [21] on potential SIC sequestration due to soil properties and the environmental conditions in which these soils formed. These soil-based constraints most likely will reduce potential SIC sequestration from $\$ 135 \mathrm{M}$ to much less (e.g., the sum of non-constrained potential SIC sequestration in Mollisols, Alfisols, and Vertisols is $\$ 70.64 \mathrm{M}$, with the remaining $\$ 64.36 \mathrm{M}$ not being realized due to soil-based constraints such as high leaching, low $\mathrm{pH}$, wind erosion, etc.). This estimate of biologically/physically non-constrained potential will be further reduced due to economic and socially/political constraints (Table 7) [21]. According to Smith et al. (2005) [21], realistic potential of greenhouse gas (GHG) mitigation may be $10 \%-20 \%$ of the biological potential or even less. 


\begin{tabular}{|c|c|c|c|}
\hline \multicolumn{4}{|c|}{$\begin{array}{l}\text { Area-normalized values }\left(\$ \mathrm{ha}^{-1}\right) \text { associated with the } \\
\text { non-constrained potential SIC sequestration from combined } \\
\text { atmospheric } \mathrm{Ca}^{2+} \text { and } \mathrm{Mg}^{2+} \text { deposition }\end{array}$} \\
\hline$\$ 0.19 \mathrm{ha}^{-1}$ & $\$ 0.35 \mathrm{ha}^{-1}$ & $\$ 0.20 \mathrm{ha}^{-1}$ & $\$ 0.16 \mathrm{ha}^{-1}$ \\
\hline Histosols & Vertisols & Mollisols & Aridisols \\
\hline 8 & & & \\
\hline \multicolumn{4}{|c|}{ <--- (Wet) ------------------- Precipitation -------------------- (Dry) ---> } \\
\hline \multicolumn{4}{|c|}{ 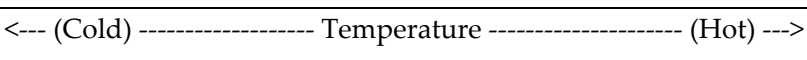 } \\
\hline \multicolumn{4}{|c|}{ 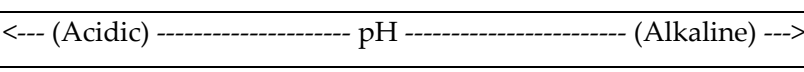 } \\
\hline
\end{tabular}

Figure 6. Expected effects (e.g., biological and physical constraints) of precipitation, temperature, and $\mathrm{pH}$ on average annual monetary values for four soil orders based on non-constrained potential soil inorganic carbon (SIC) sequestration from combined atmospheric $\mathrm{Ca}^{2+}$ and $\mathrm{Mg}^{2+}$ deposition.

Smith et al. (2005) [21] associate some values of GHG potential with only the "biological" potential (maximum value) constrained potential, which applies to SOC but excludes SIC. Total soil carbon (TSC) is composed of both SOC and SIC [22]. This study argues that using only "biological" potential excludes abiotic stocks and flows (e.g., atmospheric deposition, soil inorganic carbon, etc.), therefore "biologically/physically non-constrained" potential may be a more inclusive term to describe a wider range of processes. This newly modified conceptual framework is illustrated by using examples of abiotic stocks and flows of SIC sequestration potential from atmospheric deposition reported in this study (Table 7). Examples range from science-based boundaries/biophysical accounts (e.g., soil order) to boundary-based/administrative accounts (e.g., LRR, state, region) (Table 7). Estimated realistically achievable potential values are based on $\leq 10 \%$ [21] of biologically/physically non-constrained potential values from this study. The 10\% of "biologically/physically" (non-constrained potential in Table 7) potential for the minimum value of "socially/politically" constrained potential in Table 7 was reported based on the European croplands and may need to be revised for the U.S. croplands.

Table 7. Impact of different constraints on reducing the greenhouse gas (GHG) mitigation potential (its value) (modified from Smith et al. 2005 [21]), and examples from this study.

\begin{tabular}{|c|c|c|c|c|}
\hline \multirow[b]{3}{*}{ Account (Example) } & \multicolumn{4}{|c|}{ Maximum Value $<\longrightarrow->$ Minimum Value } \\
\hline & \multicolumn{4}{|c|}{ Greenhouse Gas (GHG) Mitigation Potential } \\
\hline & $\begin{array}{l}\text { Biologically/Physically } \\
\text { Non-Constrained Potential }\end{array}$ & $\begin{array}{l}\text { Biologically/Physically Constrained } \\
\text { Potential }\end{array}$ & $\begin{array}{c}\text { Economically Constrained } \\
\text { Potential }\end{array}$ & $\begin{array}{c}\text { Socially/Politically } \\
\text { Constrained Potential }^{1}\end{array}$ \\
\hline & Soil inorganic carbon (S & sequestration potential from atmosphe & calcium $\left(\mathrm{Ca}^{2+}\right)$ and magnesic & $\mathrm{n}\left(\mathrm{Mg}^{2+}\right)$ deposition \\
\hline \multicolumn{5}{|c|}{ 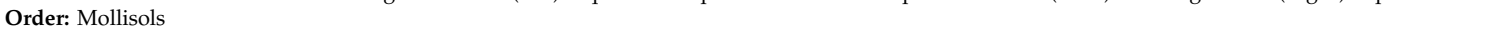 } \\
\hline Total (\$) & $3.98 \times 10^{7}$ & ? & ? & $0-3.98 \times 10^{6}$ \\
\hline Per area $\left(\$ \mathrm{ha}^{-1}\right)$ & 0.20 & ? & $?$ & $0-0.02$ \\
\hline \multicolumn{5}{|l|}{ LRR: N } \\
\hline Total (\$) & $1.15 \times 10^{7}$ & ? & $?$ & $0-1.15 \times 10^{6}$ \\
\hline Per area $\left(\$ h a^{-1}\right)$ & 0.19 & $?$ & $?$ & $0-0.02$ \\
\hline \multicolumn{5}{|l|}{ State: Texas } \\
\hline Total (\$) & $1.94 \times 10^{7}$ & ? & ? & $0-1.94 \times 10^{6}$ \\
\hline Per area $\left(\$ h^{-1}\right)$ & 0.29 & $?$ & $?$ & $0-0.03$ \\
\hline \multicolumn{5}{|l|}{ Region: Midwest } \\
\hline Total (\$) & $2.79 \times 10^{7}$ & ? & ? & $0-2.79 \times 10^{6}$ \\
\hline Per area $\left(\$\right.$ ha $\left.^{-1}\right)$ & 0.24 & ? & ? & $0-0.02$ \\
\hline
\end{tabular}


A biologically/physically non-constrained potential is based on the maximum, theoretically possible SIC sequestration potential from atmospheric $\mathrm{Ca}^{2+}$ and $\mathrm{Mg}^{2+}$ deposition without considering their actual fate in the soil. In this study, this potential was estimated for all 10 soil orders found in the contiguous U.S. A biologically/physically constrained potential is based on the actual SIC sequestration potential in a soil, which is the product of biotic (biological) and abiotic (physical) stocks and flows in the pedosphere (interface of atmosphere, biosphere, lithosphere, and hydrosphere). In this study, this potential is based on actual soil capacity to sequester SIC from atmospheric depositions. Intermediately weathered soils (Mollisols, Alfisols, and Vertisols) have been identified as having the least biologically/physically constrained potential. Economically constrained potential is based on economic activity associated with the use of soils (e.g., agricultural production, urban use, etc.). For example, soil orders of Mollisols, Alfisols, and Vertisols are typically associated with high levels of agricultural production, therefore atmospheric $\mathrm{Ca}^{2+}$ and $\mathrm{Mg}^{2+}$ deposition will be also used for provisioning (e.g., food production, etc.) ES making them less available for regulating ES. Socially/politically constrained potential is based on the existence or absence of societal and political controls over the GHG mitigation potential (e.g., legal, financial instruments).

Abiotic stocks and flows are an integral part of GHG mitigation efforts and should be included in the ES framework [23]. Mitigation efforts should be broad in scope considering different trade-offs (e.g., environmental, economic, social, political, etc.), which can be a challenge to achieve [24].

\section{Conclusions}

Regulating ES from atmospheric calcium and magnesium deposition flows, which potentially can contribute to SIC sequestration, have not been monetized in economic valuations of ES provided by the atmosphere. This study demonstrates an example of monetary valuation of non-constrained potential SIC sequestration from atmospheric calcium and magnesium deposition in the contiguous U.S. within science-based boundaries (soil order) and administrative boundaries (LRRs, states, regions) based on the concept of an avoided social cost of carbon dioxide emissions $\left(\mathrm{SC}^{-} \mathrm{CO}_{2}\right)$. Estimated total and area-normalized average annual monetary values of non-constrained potential SIC sequestration from atmospheric calcium and magnesium deposition are spatially heterogeneous. The non-constrained potential for SIC sequestration from atmospheric deposition across the contiguous U.S. was estimated to have a maximum average annual monetary value of $\$ 135 \mathrm{M}$. However, this maximum SIC sequestration potential will not be achieved due to physical, biological, economic, and other constraints. For example, agriculturally productive soil orders (Mollisols, Alfisols, and Vertisols) have a high biologically/physically non-constrained potential for SIC sequestration from atmospheric calcium and magnesium depositions, but this regulating ES will be limited by the provisioning ES demand to support crop growth, subsequent harvests, and trading. Future research on realistically achievable SIC sequestration from atmospheric calcium and magnesium deposition flows will need to quantify the degree to which these potential ecosystem flows are actually being realized by SIC sequestration in U.S. soils. Overall mitigation efforts should incorporate these abiotic stocks and flows while considering various trade-offs (e.g., environmental, economic, social, political, etc.).

Author Contributions: Conceptualization, E.A.M.; methodology, M.A.S., E.A.M., and H.A.Z.; writing-original draft preparation, E.A.M., and C.J.P.; writing-review and editing, E.A.M., C.J.P., M.A.S., and H.A.Z.; visualization, E.A.M., H.A.Z., and C.J.P. All authors have read and agreed to the published version of the manuscript.

Acknowledgments: This study was based on data from the National Atmospheric Deposition Program (NRSP-3). We would like to thank the reviewers for the constructive comments and suggestions.

Conflicts of Interest: The authors declare no conflict of interest.

\section{References}

1. MEA. Ecosystems and Human Well-Being: Synthesis; Millennium Ecosystem Assessment Series; World Resources Institute: Washington, DC, USA, 2005; p. 155. 
2. Costanza, R.; d'Arge, R.; Groot, R.; Farber, S.; Grasso, M.; Hannon, B.; Limburg, K.; Naeem, S.; O’Neill, R.V.; Paruelo, J.; et al. The value of the world's ecosystem services and natural capital. Nature 1997, 387, 253-260. [CrossRef]

3. Wood, S.L.; Jones, S.K.; Johnson, J.A.; Brauman, K.A.; Chaplin-Kramer, R.; Fremier, A.; Girvetz, E.; Gordon, L.J.; Kappel, C.V.; Mandle, L.; et al. Distilling the role of ecosystem services in the Sustainable Development Goals. Ecosyst. Serv. 2017, 29, 70-82. [CrossRef]

4. Thornes, J.; Bloss, W.; Bouzarovski, S.; Cai, X.; Chapman, L.; Clark, J.; Dessai, S.; Du, S.; van der Horst, D.; Kendall, M.; et al. Communicating the value of atmospheric services. Meteorol. Appl. 2010, 17, 243-250. [CrossRef]

5. Gray, M. The confused position of the geosciences within the "natural capital" and "ecosystem services" approaches. Ecosyst. Serv. 2018, 34, 106-112. [CrossRef]

6. Van Ree, C.C.D.F.; Van Beukering, P.J.H. Geosystem services: A concept in support of sustainable development of the subsurface. Ecosyst. Serv. 2016, 20, 30-36. [CrossRef]

7. Lal, R. Soil health and carbon management. Food Energy Secur. 2016, 5, 212-222. [CrossRef]

8. Jones, L.; Norton, L.; Austin, Z.; Browne, A.L.; Donovan, D.; Emmett, B.A.; Grabowski, Z.J.; Howard, D.C.; Jones, J.P.G.; Kenter, J.O.; et al. Stocks and flows of natural and human-derived capital in ecosystem services. Land Use Policy 2016, 52, 151-162. [CrossRef]

9. Mikhailova, E.A.; Post, C.J.; Schlautman, M.A.; Groshans, G.R.; Cope, M.P.; Zhang, L. A systems-based approach to ecosystem services valuation of various atmospheric calcium deposition flows. Resources 2019, 8, 66. [CrossRef]

10. Goddard, M.A.; Mikhailova, E.A.; Post, C.J.; Schlautman, M.A. Atmospheric $\mathrm{Mg}^{2+}$ wet deposition within the continental U.S. in relation to soil inorganic carbon sequestration. Tellus 2007, 59B, 50-56. [CrossRef]

11. Goddard, M.A.; Mikhailova, E.A.; Post, C.J.; Galbraith, J.M. Continental United States atmospheric calcium wet deposition and soil inorganic carbon stocks. Soil Sci. Soc. Am. J. 2009, 73, 989-994. [CrossRef]

12. Mikhailova, E.A.; Goddard, M.A.; Post, C.J.; Schlautman, M.A.; Galbraith, J.M. Potential contribution of combined atmospheric $\mathrm{Ca}^{2+}$ and $\mathrm{Mg}^{2+}$ wet deposition within the continental U.S. to soil inorganic carbon sequestration. Pedosphere 2013, 23, 808-814. [CrossRef]

13. NADP Program Office, Wisconsin State Laboratory of Hygiene. National Atmospheric Deposition Program (NRSP-3); NADP Program Office, Wisconsin State Laboratory of Hygiene: Madison, WI, USA, 2018; Available online: http://nadp.slh.wisc.edu (accessed on 12 February 2020).

14. ESRI. ArcGIS Desktop: Release 10.4; Environmental Systems Research Institute: Redlands, CA, USA, 2016.

15. Groshans, G.; Mikhailova, E.; Post, C.; Schlautman, M.; Zurqani, H.; Zhang, L. Assessing the value of soil inorganic carbon for ecosystem services in the contiguous United States based on liming replacement costs. Land 2018, 7, 149. [CrossRef]

16. EPA. The Social Cost of Carbon. EPA Fact Sheet. 2016. Available online: https://19january2017snapshot.epa. gov/climatechange/social-cost-carbon_.html (accessed on 15 March 2019).

17. Guo, Y.; Amundson, R.; Gong, P.; Yu, Q. Quantity and spatial variability of soil carbon in the conterminous United States. Soil Sci. Soc. Am. J. 2006, 70, 590-600. [CrossRef]

18. Fargione, J.E.; Bassett, S.; Boucher, T.; Bridgham, S.D.; Conant, R.T.; Cook-Patton, S.C.; Ellis, P.W.; Falcucci, A.; Fourqurean, J.W.; Gopalakrishna, T.; et al. Natural climate solutions for the United States. Sci. Adv. 2018, 4, eaat1869. [CrossRef] [PubMed]

19. Haan, C.T.; Barfield, B.J.; Hayes, J.C. Design Hydrology and Sedimentology for Small Catchments; Academic Press: San Diego, CA, USA, 1994.

20. Arnold, C.L.; Gibbons, C.J. Impervious surface coverage: The emergence of a key environmental indicator. Am. Planners Association J. 1996, 62, 243-258. [CrossRef]

21. Smith, P.; Andrén, O.; Karlsson, T.; Perälä, P.; Regina, K.; Rounsevell, M.; Van Wesemaels, B. Carbon sequestration potential in European croplands has been overestimated. Global Change Biol. 2005, 11, 2153-2163. [CrossRef]

22. Mikhailova, E.A.; Groshans, G.R.; Post, C.J.; Schlautman, M.A.; Post, G.C. Valuation of total soil carbon stocks in the contiguous United States based on the avoided social cost of carbon emissions. Resources 2019, 8, 157. Available online: https://doi.org/10.3390/resources8040157 (accessed on 12 February 2020). [CrossRef] 
23. Van der Meulen, E.S.; Braat, L.C.; Brils, J.M. Abiotic flows should be inherent part of ecosystem services classification. Ecosyst. Serv. 2016, 19, 1-5. [CrossRef]

24. Verspecht, A.; Vandermeulen, V.; Avest, E.T.; Van Huylenbroeck, G. Review of trade-offs and co-benefits from greenhouse gas mitigation measures in agricultural production. J. Integr. Environ. Sci. 2012, 9, 147-157. [CrossRef] 